\title{
Effect of Stirring Intervals on Biogas Production from Cow Dung and Maize Silage Mix Ratio
}

\author{
Monyluak M.Y. Chol ${ }^{1 *}$, Nicasio M. Muchuka² and Daudi M. Nyaanga ${ }^{3}$ \\ ${ }^{1}$ School of Natural Resources \& Environmental Studies, Department of Agriculture, University of Juba, P.O. Box \\ 82, Juba, South Sudan \\ ${ }^{2}$ Department of Electrical and Control Engineering, Egerton University, P.O. Box 536 - 20115, Egerton, Kenya \\ ${ }^{3}$ Department of Agricultural Engineering, Egerton University, P.O. Box 536 - 20115, Egerton, Kenya \\ Email: cholaguet@gmail.com
}

\begin{abstract}
Most biogas plants' poor performance may be attributed to inadequate stirring strategy. The study evaluated the effect of stirring intervals on biogas production from cow dung and maize silage mixture (at mixed ratio $3: 1$ ) digested in a $0.15 \mathrm{~m}^{3}$ laboratory digester at $30^{\circ} \mathrm{C}$. SIEMENS LOGO PLC and ATV12HU15M2 Drive automatically controlled the stirring of $100 \mathrm{rpm}$ for 3minutes at intervals of 1hour, 2hours, 6hours and 12hours with no stirring as control. The stirring intervals showed a significant effect on biogas production $(\mathrm{P} \leq 0.05)$ with 6 hours and 12hours increased biogas by $3.11 \%$ and $1.48 \%$, and the methane increase of $8.77 \%$ and $1.75 \%$, respectively. The 2 hours and lhour reduced biogas by $26.5 \%$ and $39.35 \%$, and methane decreased by $3.52 \%$ and $15.79 \%$, respectively compared to control (implying that the frequent stirring is not good for biogas). The stirring interval of 6hours is thus recommended for $0.15 \mathrm{~m}^{3}$ laboratory batch reactor of cow dung and maize silage.
\end{abstract}

Keywords: anaerobic digestion, biogas production, optimization, stirring intervals, maize silage.

\section{Introduction}

The immoderate use of natural resources to meet the energy needs has raised environmental, health and social concerns. It has enhanced the growing interest in searching for an alternative cleaner energy source globally $[1,2]$. In most rural areas, including in South Sudan, various biomasses such as cow dung and energy crops could be potential sources to help meet households' energy demands. Anaerobic digestion of those biomasses to produce biogas could help meet households' energy demand, reduce the pressure on natural forest, improve environmental sustainability through emission reduction of Green House Gases (GHGs) to the atmosphere and reduce waste disposal and management problems. Biogas, a renewable and environmentally friendly energy source, could provide the communities with clean nonpollutant fuel for cooking. It could also improve energy security, sanitation and health conditions of the households.

Anaerobic digestion is a natural and biological process in which methanogenic bacteria break down and convert organic materials into biogas and carbon dioxide in an oxygen-free environment [3]. Biogas is mainly a mixture of components in which methane accounts for $50-70 \%$; carbon dioxide accounts for $30-40 \%$ and low amount of other gases [4].

Optimization of anaerobic digester depends on many operational parameters. About $44 \%$ of biogas plants' poor performance may be attributed to inadequate stirring strategy [5]. Several operating parameters to anaerobic digestion must be controlled and monitored during the process to maximise the biogas production rate. These parameters influence anaerobic digestion process and enhance proper break down of organic materials for biogas production such as temperature, total solid content of the substrate, hydraulic retention time, $\mathrm{pH}$ of the slurry, Carbon to Nitrogen ratio, stirring and organic loading rate $[6,7]$.

Stirring the digester content plays an important role in maintaining a uniform environment for microorganisms in the digester. It is a physical process that uniformly distributes the digester content into different phases, forming a homogeneous substrate, nutrients, bacteria and heat throughout the digester to optimise biogas production rate [8]. Demollari, Jojic, Vorpsi, Dodona, Sallaku [9] and 
Kaparaju, Buendia, Ellegaard, Angelidaki [10] reported that stirring the digester content ensures close contact between microorganisms and particle organic materials in the digester. The process prevents stratification, the formation of surface crust and ensures that the digester's solids remain in suspension $[10,11]$. Different methods have been identified to accomplish the stirring process, including mechanical stirring, recirculation of the substrate in the digester and recirculation of the produced biogas by using circulation pump [12].

Several studies have investigated the effect of stirring system on anaerobic digestion and biogas production. But the literature reviewed so far presents conflicting findings on the effect of stirring on anaerobic digesters' performance and biogas production rate. Lin and Pearce [13] reported an increase in methane production from intermittent stirring compared to unstirred digesters. Karim, Klasson, Hoffmann, Drescher, DePaoli and Al-Dahhan [14] observed similarity in biogas production between unstirred and the stirred digesters when comparing different stirring methods including gas recirculation, slurry recirculation and impeller stirring to an unstirred setup at low solid concentration. Contrarily, Karim, Hoffmann, Klasson and Al-Dahhan [12] observed an increase in the biogas production between unstirred and the stirred digesters when comparing different stirring methods including gas recirculation, slurry recirculation and impeller stirring to an unstirred setup at high solids concentration.

Kaparaju, Buendia, Ellegaard and Angelidaki [10] evaluated the effect of stirring on biogas production from animal manure on both laboratory and pilot-scale digesters; they concluded that stirring intensity had a small effect on biogas production and minimal stirring improved biogas production. A separate study carried out by Keanoi, Hussaro and Teekasap [15] confirmed that stirring of the digester had increased the amount of biogas produced by $7.56 \%$ from natural water with cow dung and Agricultural waste at ambient temperature for 52 days retention time. El-Bakhshwan, Zayed and El-Shazly [16] studied the effect of mechanical stirring on biogas production efficiency at different speeds (30, 45, and $60 \mathrm{rpm}$ ) and stirring periods (1hour, 2hours, 3hours and 4hours) for 15 minutes stirring in large scale digester. The study showed improvement in biogas production with $60 \mathrm{rpm}$ speed giving the highest biogas production rate of $0.423 \mathrm{~m}^{3} / \mathrm{m}^{3}$ day, while the stirring period of 2hours had given the maximum biogas production rate. In a study carried out by Nandi, Saha, Huda and Alam [17] to evaluate the effect of stirring on anaerobic digestion of cow dung in a lab-scale reactor, the results showed little improvement in methane production in the reactors with stirring compared to reactors without stirring and ambient condition. The study indicated that stirring does not affect anaerobic digestion of cow dung.

Concerning the stirring speed (intensity), many researchers are in agreement that changing stirring intensity does not affect biogas production. Ong, Greenfield and Pullammanappallil [18] found no difference in biogas production when comparing different stirring intensities (100-200 rpm). Similarly, Hoffmann, Garcia, Veskivar, Karim, Al-Dahhan and Angenent [19] noticed no difference in biogas yield when varying stirring intensities from (50 to $1500 \mathrm{rpm}$ ). The stirring intensity was found to have an effect on biogas production when stirring at high intensities. Stafford [20] observed a reduction in biogas production when stirring at high intensities from (700 to $1000 \mathrm{rpm}$ ) during intermittent stirring system, while lower stirring intensities from (140 to $425 \mathrm{rpm}$ ) showed similar biogas production when treating sewage sludge.

This study evaluated the effect of different stirring intervals on biogas production from cow dung and maize silage mixture as a substrate (at ratio $3: 1$ ) digested in a $0.15 \mathrm{~m}^{3}$ laboratory anaerobic digester at a temperature of $30^{\circ} \mathrm{C}$ for 15 days of retention time each treatment. The stirring intervals were evaluated at a constant speed of 100 revolutions per minute (rpm) for 3 minutes stirring at different intervals of 1 hour, 2 hours, 6 hours and 12 hours with no stirring as control. The stirring process was automatically controlled by Programmable Logic Controller (PLC) running on SIEMENS LOGO and ATV12HU15M2 Drive using (2HP, 415V 3.9A) motor rated at $1400 \mathrm{rpm}$ to $100 \mathrm{rpm}$.

\section{Materials and Methods}

\subsection{Material Preparations}

The materials for this study were maize silage and cow dung. Maize was harvested from Njoro maize farms, and the silage was prepared at Egerton University Agricultural Engineering biogas lab in Kenya. The preparation included chopping the whole plant into smaller lengths of 7-8 $\mathrm{mm}$ [21] by using a 
chopping machine. The chopped maize was stored in well-closed plastic bags (silage bags) for two months to ferment the silage properly. Fresh cow dung was collected from Egerton University Farm (Tatton Farm). The stones and other unwanted materials were first removed from cow dung before mixing it with maize silage (MS) at a mixed ratio 3:1 (75\%CD: 25\% MS) [22, 23]. Then, the substrate mixed ratio of cow dung and maize silage was diluted with water at TS of $8 \%$ to make a slurry that was fed into fixed dome lab digester for biogas production

\subsection{Experimental Setup}

The laboratory anaerobic digestion system used for this study mainly consists of four units: digestion unit, heating unit, stirring system and the control panel.

The digester has a maximum volume of $0.15 \mathrm{~m}^{3}$ with a net capacity of $0.12 \mathrm{~m}^{3}$ and is enclosed by a water jacket, as shown in Figure 1. The digestion unit consists of a feeding chamber connected by a pipe to the digester used for feeding the digester with the substrate, expansion chamber used to expand and remove the effluent from the digester and a water jacket used for the thermoregulation of the digester's temperature. Hot water is pumped to the water jacket from an external water heating tank and circulated around the digester to thermoregulate its temperature. The heating unit consists of an external water tank with an immersed heaters connected by a centrifugal pump to circulate hot water around the digester. The circulation of hot water between the water jacket and the external heater allows precise temperature control of the digester.

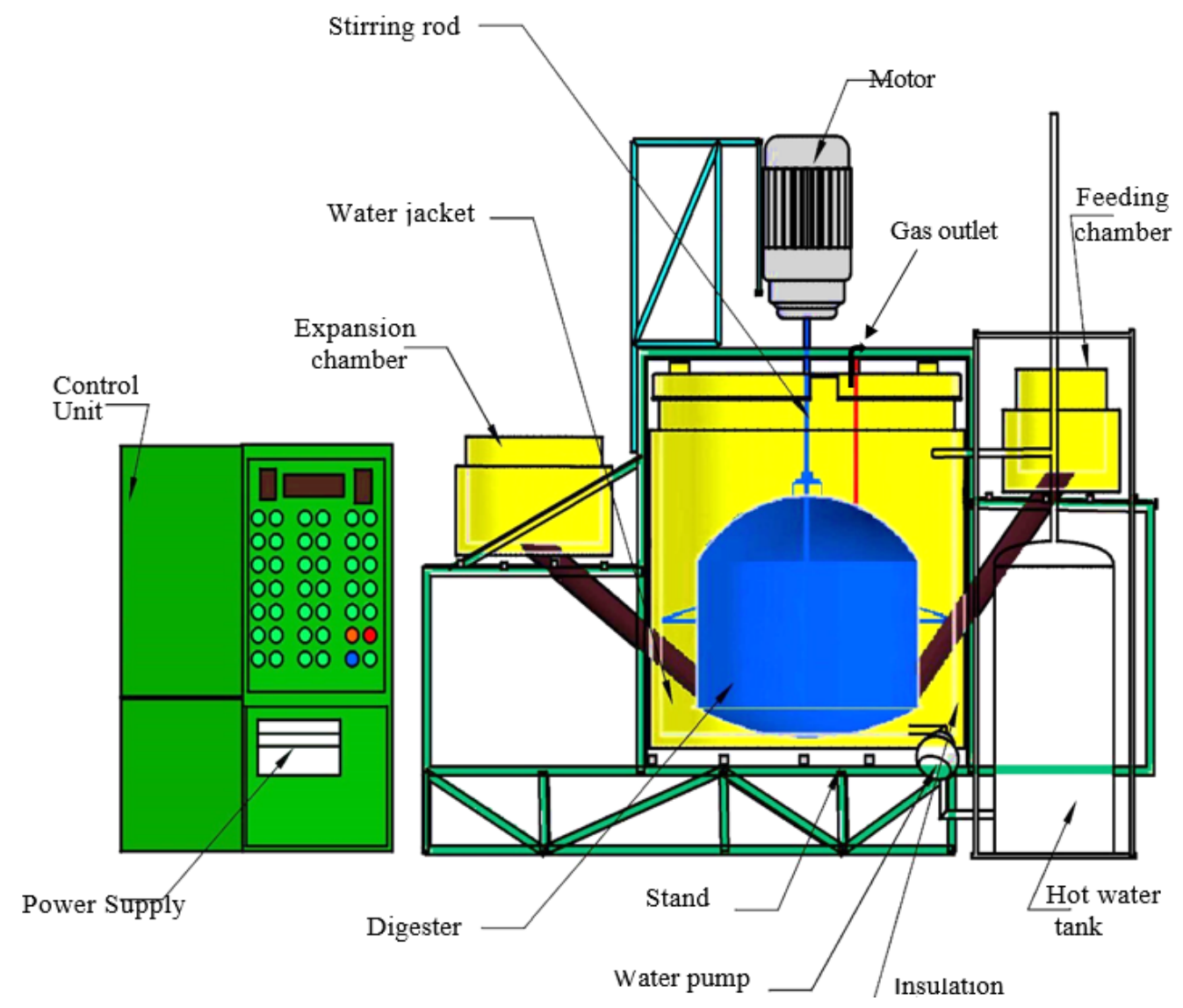

Figure 1. Laboratory anaerobic digestion system

A three-phase induction motor is connected to stirring rod for mixing the substrate in the digester. The stirring speed and intervals were controlled by the Schneider Electric variable frequency drive (ATV12HU15M2) and Programmable Logic Controller (PLC) running on SIEMENS LOGO. The control panel interfaces to the electrical system consisting of a power supply, (PLC), Schneider Electric 
variable frequency drive (ATV12HU15M2), Multispan UTC 421 Programmable Temperature Controller and setting buttons used by the operator to control the system in the digester such as temperature and the stirring intervals. Biogas generated from the digester is collected through a biogas collection chamber using the water displacement method.

\subsection{Substrate Pertinent Characteristics}

Before the digestion process, feedstocks (cow dung and maize silage) were analysed for Total solids (TS, \%), volatile solids (VS, \%), Total Carbon (TC) and Total Nitrogen (TN) using the protocols given in Table 1 at the laboratories of Egerton University and Kenya Agricultural and Livestock Research Organisation (KALRO).

Table1. Physical and chemical analysis methods used for the substrate samples.

\begin{tabular}{llr}
\hline Parameter & \multicolumn{1}{c}{ Description of the method } & Reference \\
\hline TS (\%) & Drying the sample in the laboratory oven at a temperature of $105^{\circ} \mathrm{C}$ for an hour. & {$[24]$} \\
VS (\%) & $\begin{array}{l}\text { The residue obtained from total solids was ignited at a temperature of } 550{ }^{\circ} \mathrm{C} \text { to a } \\
\text { constant weight using a muffle furnace. }\end{array}$ & {$[24]$} \\
TC (\%) & $\begin{array}{l}\text { Calorimetric: Organic carbon in the sample is oxidized by acidified dichromate at } 150{ }^{\circ} \mathrm{C} \\
\text { for } 30 \text { minutes. Barium chloride is added to the cool digests. The carbon concentration is }\end{array}$ & {$[25]$} \\
& $\begin{array}{l}\text { read on the spectrophotometer at } 600 \mathrm{~nm} \text {. } \\
\text { TN }(\%)\end{array}$ & $\begin{array}{l}\text { Digestion of feedstock in a tube with } \mathrm{H}_{2} \mathrm{SO}_{4}-\text { Salicylic Acid- } \mathrm{H}_{2} \mathrm{O}_{2} \text { and Selenium. The } \\
\text { digestion completed by concentrated } \mathrm{H}_{2} \mathrm{SO}_{4} \text { at elevated }\left(330^{\circ} \mathrm{C}\right) \text { under the influence of Se }\end{array}$ \\
& $\begin{array}{l}\text { as a catalyst. Nitrogen was measured by distillation followed by titration with } \\
\text { standardized } 0.3 \mathrm{~N} \mathrm{HCL} .\end{array}$ \\
\hline
\end{tabular}

${ }^{*} T S=$ Total Solid, VS= Volatile Solid, $H C L=$ Hydrochloric acid, $S_{e}=$ Selenium, $\mathrm{H}_{2} \mathrm{O}_{2}=$ Hydrogen peroxide, $\mathrm{H}_{2} \mathrm{SO}_{4}=$ Sulfuric acid, $\mathrm{TC}=$ Total Carbon, TN= Total Nitrogen.

\subsection{Experimental Design}

The effect of mechanical stirring at a constant speed of $100 \mathrm{rpm}$ for 3 minutes stirring at different intervals on biogas production was evaluated by stirring the digester at different intervals of 1 hour, 2 hours, 6 hours and 12 hours with no stirring as a control for 15 days of retention time each treatment. Table 2 showed stirring intervals at a constant speed operated at a temperature of $30^{\circ} \mathrm{C}$. The Schneider Electric variable frequency drive (ATV12HU15M2) controls the speed of the (2HP, 415V 3.9A) motor rated at $1400 \mathrm{rpm}$ to $100 \mathrm{rpm}$. The stirring intervals were automatically controlled by Programmable Logic Controller (PLC) running on SIEMENS LOGO PLC (Figure 2).

The substrate was prepared at $8 \%$ TS by diluting the feedstock at mixed ratio 3:1 of cow dung and maize silage with water to make a slurry of $120 \mathrm{~kg}$ that was fed into the digester using the formula 1 and 2 below. In the process, $51.336 \mathrm{~kg}$ of cow dung and maize silage mixed ratio with $18.7 \%$ TS (Table 3) was measured and diluted with $68.664 \mathrm{~kg}$ of water at ratio (1: 1.337). The diluted substrate was then stirred for 10 minutes until a slurry with a uniform consistency was achieved. The mixed slurry was then poured into the digester, and the biogas production was recorded daily using water displacement method until the decline in the daily biogas production was realized. The quality of biogas produced was analysed by portable pump composite gas analyser (HFP-0401, portable 4IN1 gas detector) to determine methane percentage.

The respective masses of substrate and water were prepared at $8 \% \mathrm{TS}$ to make a slurry of $120 \mathrm{~kg}$ and were given by equations 1 and 2 .

The required mass to prepare $120 \mathrm{~kg}$ of the substrate is given by:

$$
\text { Mass of substrate }=\left\{\frac{8}{\mathrm{y}} * 120\right\} \mathrm{kg}
$$

The required water to prepare $120 \mathrm{~kg}$ of the substrate is given by:

$$
\text { Mass of water }=\left\{1-\frac{8}{\mathrm{y}}\right\} * 120 \mathrm{~kg}
$$


where $\mathrm{Y}=\mathrm{TS}$ of the sample

Table 2. Different stirring intervals at a constant speed of $100 \mathrm{rpm}$ for 3 minutes stirring period.

\begin{tabular}{cccccccc}
\hline & & & & \multicolumn{4}{c}{ Influent at 8\% TS } \\
\cline { 6 - 8 } Treatments & $\begin{array}{c}\text { Temperature } \\
\left({ }^{\circ} \mathrm{C}\right)\end{array}$ & $\begin{array}{c}\text { Speed } \\
(\mathrm{rpm})\end{array}$ & $\begin{array}{c}\text { Stirring } \\
\text { interval }\end{array}$ & CD75:MS25 & $\begin{array}{c}\text { Feedstock } \\
\left\{\frac{8}{\mathrm{y}} * 120\right\} \mathrm{kg}\end{array}$ & $\begin{array}{c}\text { Water } \\
\left\{1-\frac{8}{\mathrm{y}}\right\} * 120 \mathrm{~kg}\end{array}$ & $\begin{array}{c}\text { Feedstock: } \\
\text { water ratio }\end{array}$ \\
\hline T1 & 30 & - & Control & $3: 1$ & 51.336 & 68.664 & $1: 1.337$ \\
T2 & 30 & 100 & 1hour & $3: 1$ & 51.336 & 68.664 & $1: 1.337$ \\
T3 & 30 & 100 & 2hours & $3: 1$ & 51.336 & 68.664 & $1: 1.337$ \\
T4 & 30 & 100 & 6hours & $3: 1$ & 51.336 & 68.664 & $1: 1.337$ \\
T5 & 30 & 100 & 12hours & $3: 1$ & 51.336 & 68.664 & $1: 1.337$ \\
\hline
\end{tabular}

$Y=T S$ of the sample $=18.7$, Control= without stirring, $C D=$ Cow Dung, MS=Maize Silage.

The PLC programme running on SIEMENS LOGO PLC to control the stirring intervals of the digester. The programming language used in the PLC programming in this work is the functional block diagram (FBD). In this programme, blocks were used to achieve different functions in the programme. The programme to control the stirring intervals is as shown in Figure 2.

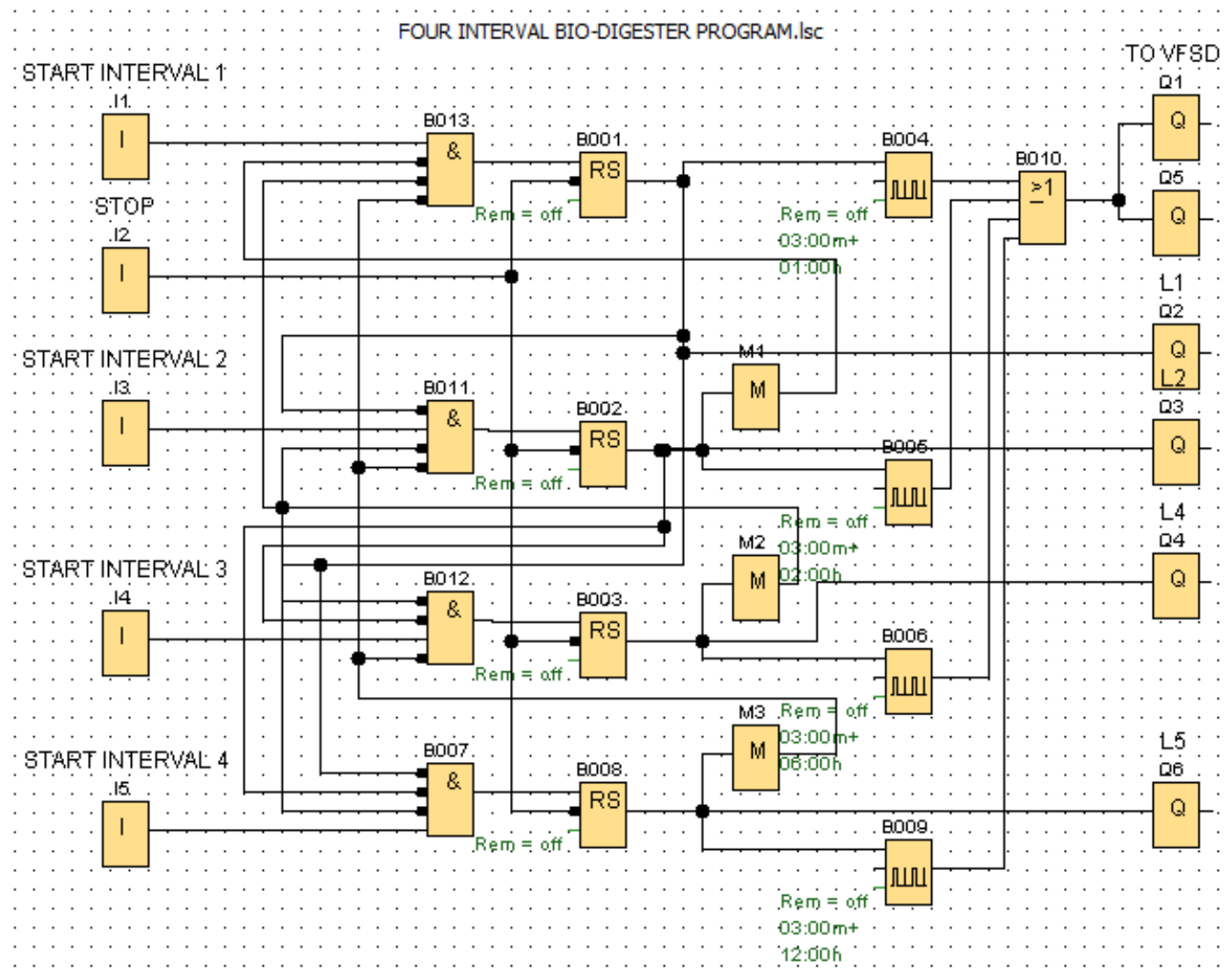

Figure 2. PLC four interval stirrer control programme

The programme's operation was such that the first treatment was carried out by enabling the stirring through input one (I1). When the input one button is pressed (A normally open (NO) pushbutton), the first stirring interval is started, and an indicating light next to the button turns on. The stirrer runs for 3 minutes and stops for one hour then repeats the sequence. The input two (I2) is the stop pushbutton (NO). When pressed, it stops any running stirring interval mode. When the input three (I3) push button is pressed (NO), the second stirring interval is started and is indicated by the light emitter near 
the second push button. The stirrer runs for 3minutes and stops for two hours then repeats the sequence. When the input four (I4) is activated by pressing a pushbutton (NO), the third stirring interval is started and is indicated by the light indicator near the third push button. The stirrer runs for 3minutes and stops for six hours then repeats the sequence. When the input five (I5) is activated by pressing a pushbutton $(\mathrm{NO})$, the forth stirring interval is started and is indicated by the light indicator near the forth push button. The stirrer runs for 3minutes and stops for twelve hours then repeats the sequence.

The output Q1 is wired to the variable frequency drive that receives the control signal and turns on and off the motor appropriately, while the output Q5 triggers the turning on/off of the motor status light indicator. The other outputs Q2, Q3, Q4 and Q6 are programmed to activate/deactivate the light indicators corresponding to the selected stirring interval.

\subsection{Biogas Production and Analysis}

Biogas measurement was done using a water displacement method. The daily biogas generated from the digester passes through the gas outlet. A graduated glass cylinder of $500 \mathrm{ml}$ capacity was used as a gas holder and was filled with water and kept in an inverted position in a water bucket. As the biogas was released from a controlled valve through a plastic tube. It displaced water in the cylinder into a bucket of water due to the biogas pressure, and the biogas was recorded at a set point. The process was repeated several times until the daily produced biogas was exhausted. The volume of biogas produced per day was then calculated for the production rate in cubic metre per cubic metre of the digester volume per day $\left(\mathrm{m}^{3} / \mathrm{m}^{3}\right.$ day $)[27,28]$.

Biogas composition was analysed by using portable pump composite gas analyser (HFP-0401, portable 4IN1 gas detector) to determine the methane concentration from the biogas sample being pumped into the system. The analyser is equipped with a sensor to detect the lower explosive limit (LEL) of methane gas at which it was calibrated. The low explosive level (LEL) of methane was reported to be $4.9 \%$ which is approximately $5 \%$ by volume [29]. The analyser works by signifying a high level of methane gas through a series of audible and visible indicators (light flashes, alarm sounds and vibration) at a response time $\leq 20 \mathrm{~s}$. The sensor response serves as the reference point or scale, and when the sensor's response surpasses a certain pre-set level, an alarm is activated. The low explosive level (LEL) of the methane in the sample is recorded and calculated by dividing its concentration by the $100 \%$ LEL of methane $(5 \%)$.

\subsection{Data Analysis}

Data were analysed by using the data analysis Toolbox (Microsoft Excel, 2010).

One way (ANOVA) was carried out using SAS software for windows 8.2 (TS2M0) 1999-2001 by (SAS Institute Inc., Cary, NC, USA). The means of treatment values were separated using Fisher's least significant difference (Fisher's LSD) at $\mathrm{p} \leq 0.05$.

\section{Results}

\subsection{Physical and Chemical Characteristics of Substrates}

Feedstocks were analysed for $\mathrm{TS} \%, \mathrm{VS} \%, \mathrm{C}, \mathrm{N}$ and $\mathrm{C} / \mathrm{N}$ before the digestion process, and the results were presented in Table 3 below.

Table 3. Physical and chemical characteristics of samples mix ratios

\begin{tabular}{lcccccc}
\hline \multirow{2}{*}{ Samples } & \multirow{2}{*}{ Ratio } & \multicolumn{5}{c}{ Parameters } \\
\cline { 3 - 7 } & & TS* $(\%)$ & VS $(\%)$ & C (\%) & N (\%) & C/N ratio \\
\hline $100 \%$ CD $+00 \%$ MS & $1: 00$ & 16.1 & 87.0 & 5.34 & 0.38 & 14.1 \\
$00 \%$ CD $+100 \%$ MS & $0: 01$ & 31.6 & 78.8 & 22.3 & 0.58 & 38.4 \\
$75 \%$ CD $+25 \%$ MS & $3: 01$ & 18.7 & 87.2 & - & - & - \\
\hline
\end{tabular}


${ }^{*} T S=$ Total solids, VS= Volatile Solids, C= Total Carbon, $N=$ Total Nitrogen, $C / N=$ carbon to nitrogen ratio, $C D=$ Cow Dung, $M S=$ Maize Silage.

\subsection{Effect of Mechanical Stirring Intervals on Biogas Production}

The effect of mechanical stirring intervals on biogas production was evaluated at a constant speed of 100 rpm for 3 minutes at different stirring intervals of 1 hour, 2 hours, 6 hours and 12 hours with no stirring as a control. The digester was operated at a constant temperature of $30^{\circ} \mathrm{C}$, and the substrate $(3: 1 \mathrm{cow}$ dung and maize silage) was prepared at TS of $8 \%$ to make a slurry of $120 \mathrm{~kg}$. The daily biogas production $\left(\mathrm{m}^{3} / \mathrm{m}^{3} \mathrm{~d}\right)$ was recorded and presented graphically in Figure 3. The total biogas and methane production was presented in Table 4 . The trend of the total biogas production and methane percentage for the digester operated at different stirring intervals was presented in Figure 4. The ANOVA results shows that different stirring intervals had a significant effect on biogas production at $\mathrm{F}=19.03, \mathrm{P} \leq 0001$. The LSD $t$ test on the effect of different stirring intervals on biogas production showed that the control (without stirring), the stirring interval of 6hours and the stirring interval of 12 hours were not significantly different from each other at $\mathrm{P} \leq 0.05$. Similarly, the stirring intervals of 1 hour and 2 hours were not significantly different from each other at $\mathrm{P} \leq 0.05$.

Table 4. Results of biogas production from different stirring intervals for 3:1 cow dung to maize silage substrate digested at $30^{\circ} \mathrm{C}$ for 15 days.

\begin{tabular}{cccc}
\hline \multirow{2}{*}{ Stirring intervals } & \multicolumn{3}{c}{ Biogas production } \\
\cline { 2 - 4 } & Average Biogas $\left(\mathrm{m}^{3} / \mathrm{m}^{3} \mathrm{~d}\right)$ & Total Biogas $\left(\mathrm{m}^{3}\right)$ & Methane $(\%)$ \\
\hline Control (no stirring) & $0.405^{\mathrm{a}}$ & 6.071 & 57 \\
1 hour & $0.246^{\mathrm{c}}$ & 3.685 & 48 \\
2 hours & $0.297^{\mathrm{b}}$ & 4.462 & 55 \\
6 hours & $0.417^{\mathrm{a}}$ & 6.260 & 62 \\
12 hours & $0.411^{\mathrm{a}}$ & 6.161 & 58 \\
\hline
\end{tabular}

The means with the same alphabets (superscript) are not significantly different at $P \leqslant 0.05$

Table 4 presents the results at stirring of $100 \mathrm{rpm}$ for 3 minutes at intervals of 1 hour, 2 hours, 6 hours and 12 hours with no stirring as control.

The ANOVA results shows that different stirring intervals had a significant effect on biogas production at $\mathrm{F}=19.03, \mathrm{P} \leq 0.05$. The daily data recorded from different stirring intervals of the control (no stirring), 1 hour, 2 hours, 6 hours and 12 hours were plotted in figure 3 below. 


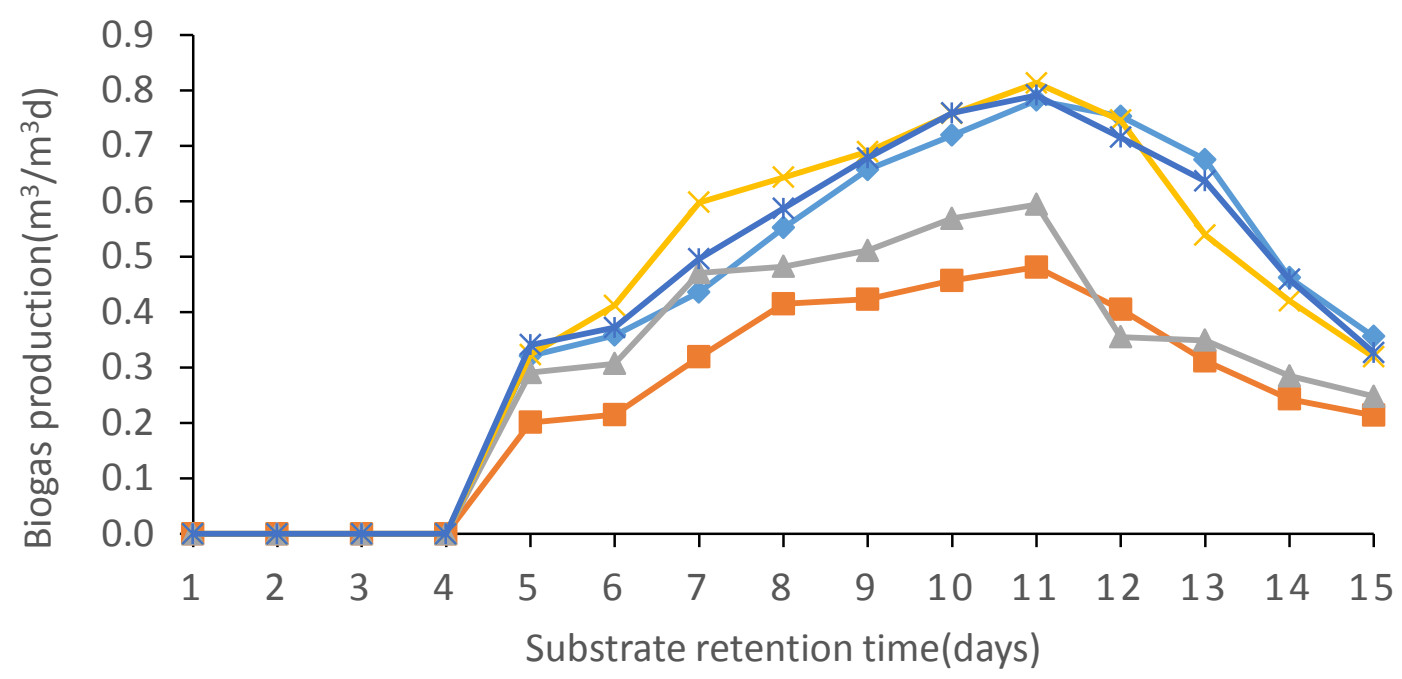

$\multimap$ Control $\rightarrow-1$ hour $\leftarrow 2$ hours $\leftarrow 6$ hours $* 12$ hours

Figure 3. Daily biogas production trend of different stirring intervals.

Figure 3 illustrates the daily biogas production trend for 15 days retention time at different stirring intervals of control, 1 hour, 2 hours, 6 hours and 12 hours.

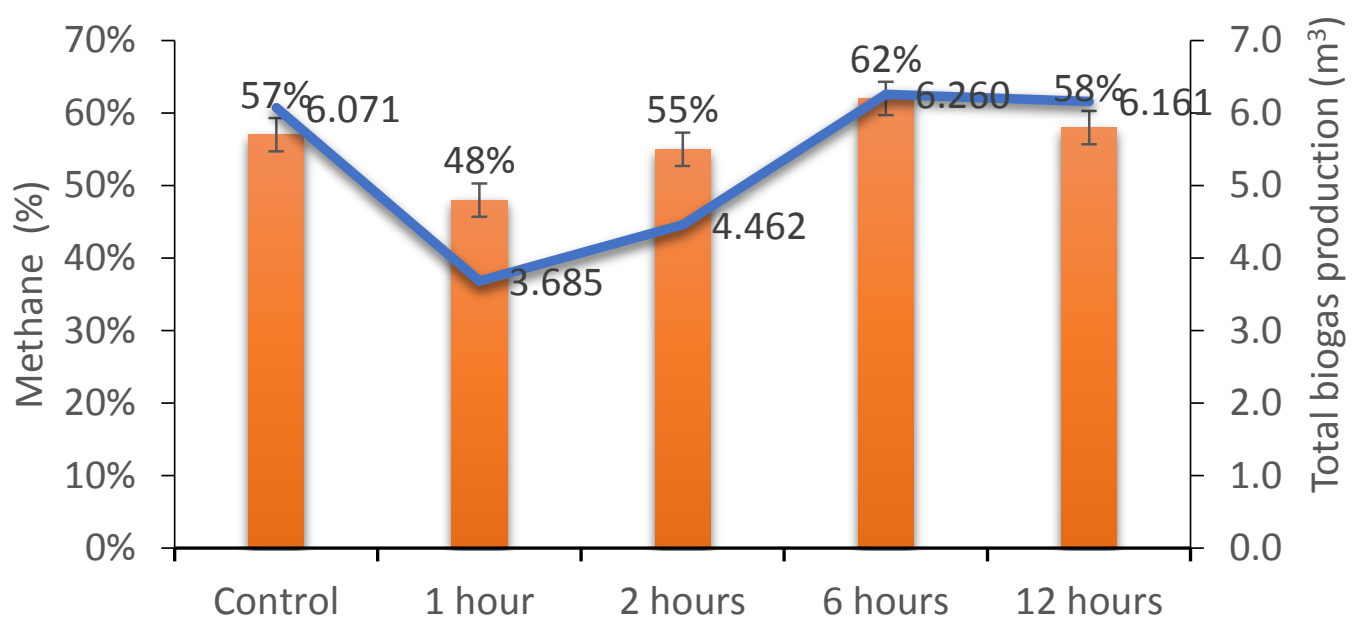

Stirring Intervals (hrs)

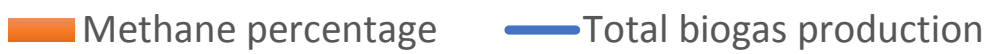

Figure 4. Total biogas production and methane percentage for different stirring intervals.

Figure 4 presents the total volume of biogas production and methane percentage for the stirring of $100 \mathrm{rpm}$ for 3 minutes stirring at different intervals of control (without stirring), 1 hour, 2 hours, 6 hours and 12 hours. 


\section{Discussions}

There was no biogas observed for all the stirring intervals in the first four days of the digester retention time. That delay of biogas production at the initial stage was attributed to the slow microbial activity due to strong activity of hydrolysis. The strong hydrolysis activity at the initial stage of anaerobic digestion was observed in the first five days. It was revealed by directly burning the biogas produced daily using matchsticks. The unburnable biogas in the first four days of the retention time was an indication that carbon dioxide $\left(\mathrm{CO}_{2}\right)$ is higher than methane $\left(\mathrm{CH}_{4}\right)$ in the biogas produced [30]. While burning the biogas produced daily revealed the strong activity of methanogens, the burnable biogas on day 5 was an indication that methane $\left(\mathrm{CH}_{4}\right)$ was higher than carbon dioxide $\left(\mathrm{CO}_{2}\right)$ in the biogas produced [30]. Thereafter, the production increased gradually until the peak was reached on day 11 for all stirring intervals due to the increasing activities of methanogenic bacteria in the digester. After the peak, biogas production started to decline gradually for the remaining days of the retention time due to the depletion of biodegradable organic materials in the digester, resulting in slow microbial activities as shown in Figure 3.

The results showed that at stirring interval of 6hours, the digester recorded higher total biogas production of $6.260 \mathrm{~m}^{3}$ followed by $6.161 \mathrm{~m}^{3}, 6.071 \mathrm{~m}^{3}, 4.462 \mathrm{~m}^{3}$ and $3.685 \mathrm{~m}^{3}$ recorded at the stirring intervals of 12 hours, control (without stirring), 2 hours and 1 hour respectively. Different stirring intervals had a direct effect on biogas production as they were significantly different at $\mathrm{P} \leq 0.05$. The control (without stirring), the stirring interval of 6hours and the stirring interval of 12 hours were not significantly different from each other at $\mathrm{P} \leq 0.05$. Similarly, the stirring intervals of 1 hour and 2 hours were not significantly different from each other at $\mathrm{P} \leq 0.05$.

The methane percentage accounts for $62 \%, 58 \%, 57 \%, 55 \%$ and $48 \%$ recorded at 6hours, 12 hours, control, 2hours and 1hour respectively. The total biogas production increased by $3.11 \%$ and $1.48 \%$ at stirring intervals of 6 hours and 12 hours. Contrarily, the total biogas production decreased by $26.5 \%$ and $39.3 \%$ with the stirring intervals of 2 hours and 1hour respectively compared to the control. The methane content increased by $8.77 \%$ and $1.75 \%$ at stirring intervals of 6 hours and 12 hours, while it has decreased by $3.52 \%$ and $15.79 \%$ at stirring intervals of 2 hours and 1 hour compared to the control (without stirring).

The evaluated stirring intervals showed that with longer intermittent stirring interval, the biogas and methane content increased. But too long intermittent stirring interval such as the case in the stirring interval of 12 hours, there was no effect on biogas and methane production and that could be attributed to the fact that too long intermittent stirring interval was not sufficient enough to distribute the nutrients and heat uniformly inside the digester. While stirring the digester for 3minutes intermittently every 6 hours was sufficient to mix the digester content and maintain a uniform environment for biological processes without disturbing the activity of microorganisms as stated by Demollari, Jojic, Vorpsi, Dodona and Sallaku [9], hence, increases the biogas and methane production rate. Contrarily, with the shorter intermittent stirring intervals, biogas and methane production decreased compared to the control (without stirring). The shorter intermittent stirring interval could affect and disturb the microorganisms in the digester and slow their activities for biogas production [10, 31].

The results obtained in this study so far agreed with the results reported by Sulaiman, Hassan, Shirai, Abd-Aziz, Tabatabaei, Busu and Yacob [31]. They reported a decrease in biogas production when increasing the stirring intervals from 6 hours to 2 hours at an intermittent stirring for 30 minutes period using sludge recirculation. Contrarily, this results disagreed with the results obtained by El-Bakhshwan, El-Ghafar, Zayed and El-Shazly [16] as they achieved maximum biogas production at stirring interval of 2 hours at a shorter intermittent stirring for 15 minutes period using a mechanical stirring technique.

\section{Conclusions}

The results obtained from evaluating the effect of different stirring intervals on biogas production had shown that at stirring interval of 6hours, the digester recorded higher total biogas production of 6.260 $\mathrm{m}^{3}$ followed by $6.161 \mathrm{~m}^{3}, 6.071 \mathrm{~m}^{3}, 4.462 \mathrm{~m}^{3}$ and $3.685 \mathrm{~m}^{3}$ recorded at 12 hours, control (without stirring), 2 hours and 1 hour respectively. The methane percentage accounts for $62 \%, 58 \%, 57 \%, 55 \%$ and $48 \%$ recorded at 6 hours, 12 hours, control, 2 hours and 1 hour respectively. 
Based on the results obtained so far, the study thus recommends the stirring interval of 6 hours for a $0.15 \mathrm{~m}^{3}$ laboratory temperature-controlled fixed-dome anaerobic digester of cow dung and maize silage as a substrate when fed as a batch system.

Acknowledgement. The research project was funded by the Centre of Excellence in Sustainable Agriculture and Agribusiness Management (CESAAM), Egerton University.

\section{References}

1. Nsair A, Onen Cinar S, Alassali A, Abu Qdais H, Kuchta K. Operational parameters of biogas plants: A review and evaluation study. Energies. 2020; 13 (15):3761.

2. Hren R, Petrovic A, Cucek L, Simonic M. Determination of Various Parameters during Thermal and Biological Pre-treatment of Waste Materials. Energies. 2020; 13 (9):2262.

3. Molino A, Nanna F, Ding Y, Bikson B, Braccio G. Bio-methane. Production by anaerobic digestion of organic waste. Fuel. 2013; 103: 1003-1009.

4. Nallamothu RB, Teferra A, Rao BA. Biogas purification, compression and bottling. Global Journal of Engineering, Design and Technology. 2013; 2 (6):34-8.

5. Hopfner-Sixt K, Amon T. Monitoring of agricultural biogas plants in Austria-Mixing technology and specific values of essential process parameters. In Proceedings of the 15th European Biomass Conference and Exhibition, Berlin, Germany 2007 (Vol. 711, p. 17181728).

6. Adekunle KF, Okolie J A. A review of the biochemical process of anaerobic digestion. Advances in Bioscience and Biotechnology. 2015; 6 (03):205-212.

7. Zielinski M, Kisielewska M, Debowski M, Elbruda K. Effects of nutrients supplementation on enhanced biogas production from maize silage and cattle slurry mixture. Water, Air, and Soil Pollution. 2019; 230 (6):117.

8. Lemmer A, Naegele HJ, Sondermann J. How efficient are agitators in biogas digesters? Determination of the efficiency of submersible motor mixers and incline agitators by measuring nutrient distribution in full-scale agricultural biogas digesters. Energies. 2013; 6(12): 6255-6273.

9. Demollari E, Jojic E, Vorpsi V, Dodona E, Sallaku E. Temperature and Stirring Effect of Biogas Production from Two Different Systems. American Journal of Energy Engineering. 2017; 5 (2): 6-10.

10. Kaparaju P, Buendia I, Ellegaard L, Angelidakia I. Effects of mixing on methane production during thermophilic anaerobic digestion of manure: Lab-scale and pilot-scale studies. Bioresource technology. 2008; 99 (11): 4919-4928.

11. Del Real Olvera J, Lopez-Lopez A. Biogas production from anaerobic treatment of agro-industrial wastewater. Biogas. Rijeka: In Tech. 2012; 14: 91-112.

12. Karim K, Hoffmann R, Klasson T, Al-Dahhan MH. Anaerobic digestion of animal waste: Waste strength versus the impact of mixing. Bioresource technology. 2005; 96 (16): 1771-81.

13. Lin KC, Pearce ME. Effects of mixing on anaerobic treatment of potato-processing wastewater. Canadian journal of civil engineering. 1991; 18 (3): 504-514.

14. Karim K, Klasson KT, Hoffmann R, Drescher SR, DePaoli DW, Al-Dahhan MH. Anaerobic digestion of animal waste: Effect of mixing. Bioresource technology. 2005; 96 (14):1607-1612.

15. Keanoi N, Hussaro K, Teekasap S. Effect of with/without agitation of agricultural waste on biogas production from anaerobic co-digestion-a small scale. American Journal of Environmental Sciences. 2014; 10 (1): 74-85.

16. El-Bakhshwan M, El-Ghafar A, Zayed M, El-Shazly A. Effect of mechanical stirring on biogas production efficiency in large scale digesters. Journal of Soil Sciences and Agricultural Engineering. 2015; 6 (1): 47-63.

17. Nandi R, Saha CK, Alam MM. Effect of Mixing on Biogas Production from Cow dung. Eco-friendly Agriculture Journal. 2017; 10: 7-13.

18. Ong HK, Greenfield PF, Pullammanappallil PC. Effect of mixing on biomethanation of cattle-manure slurry. Environmental technology. 2002; 23 (10):1081-1090.

19. Hoffmann RA, Garcia ML, Veskivar M, Karim K, Al-Dahhan MH, Angenent LT. Effect of shear on performance and microbial ecology of continuously stirred anaerobic digesters treating animal manure. Biotechnology and bioengineering. 2008; 1100 (1):38-48.

20. Stafford DA. The effects of mixing and volatile fatty acid concentrations on anaerobic digester performance. Biomass. 1982; 2 (1):43-55.

21. Herrmann C, Prochnow A, Heiermann M, Idler C. Particle size reduction during harvesting of crop feedstock for 
biogas production II: effects on energy balance, greenhouse gas emissions and profitability. Bioenergy Research. 2012; 5 (4): 937-948.

22. Ayhan A, Liu Q, Alİbas K, Unal H. Biogas production from maize silage and dairy cattle manure. Journal of Animal and Veterinary Advances. 2013; 12 (5): 553-556.

23. Monyluak M.Y. Chol. MSc [Unpublished thesis]: Effect of maize silage and cow dung mix ratios, temperature and stirring intervals on biogas production. Egerton University, Nakuru: 2020.

24. EPA (Environmental Protection Agency). Method 1684 Total, Fixed and Volatile Solids in Water, Solids, and Biosolids. 2001; ( 4303 ): 1-13.

25. Anderson JM, Ingram JS. A handbook of methods. CAB International, Wallingford, Oxfordshire. 1993; 221: 6265.

26. Walinga I, Van Vark W, Houba VJ, Van der Lee JJ. Soil and plant analysis. Part 7. 1989; 7: 13-16.

27. Mudhoo A, Moorateeah PR, Mohee R. Effects of Microwave Heating on Biogas Production, Chemical Oxygen Demand and Volatile Solids. Int. J. Environ. Chem. Ecol. Geol. Geophy. Eng. 2012; 6 (9): 609-614.

28. Masinde, B. H., Nyaanga, D. M., Njue, M. R., Matofari, J. W. Effect of Total Solids on Biogas Production in a Fixed Dome Laboratory Digester under Mesophilic Temperature. Annals of Advanced Agricultural Sciences. 2020; 4: 26-33.

29. Hodgkinson J, Pride RD. Methane-specific gas detectors: the effect of natural gas composition. Measurement Science and Technology. 2010; 21 (10): 105103.

30. Borhan MS. Dry anaerobic digestion of fresh feed yard manure: a case study in a laboratory setting. International Journal of Emerging Sciences. 2012; 2 (4): 509-525.

31. Sulaiman A, Hassan MA, Shirai Y, Abd-Aziz S, Tabatabaei M, Busu Z, Yacob S. The Effect of Mixing on Methane Production in a Semi-commercial Closed Digester Tank Treating Palm Oil Mill Effluent. Australian Journal of Basic and Applied Sciences. 2009; 3 (3): 1577-1583. 